\title{
Models and Optimization of Rice Husk Ash-Clay Soil
} Stabilization

\author{
Iloeje Amechi Francis ${ }^{1}$ and Aniago Venantus ${ }^{2}$ \\ 1. Department of Architecture, Enugu State University of Science and Technology, Enugu 400261, Nigeria \\ 2. Department of Civil Engineering, Enugu State University of Science and Technology, Enugu 400261, Nigeria
}

\begin{abstract}
Soil stabilization has been found to be very effective in upgrading the bearing capacity of weak soils for construction purposes. The stabilizing agent, for cost efficiency, ought to provide a cheaper alternative to other possible processes. With the rapid industrialization efforts around the globe, enormous quantities of waste materials are generated and there has not been adequate mechanism for recycling and re-use of such wastes to reduce the consequent environmental problems and hazardous situations created as a result. The objective of the study is to upgrade expansive soils from Eke Obinagu, Ugwuaji in Enugu State and Egbede in Abia State Nigeria, as constructions material using RHA (rice husk ash). Expansive clay soils were mixed with this ash, remolded and tested to examine the effect on the OMC (optimum moisture content) and the CBR (California Bearing Ratio). The characterization of the soils was done in accordance with BS1377 and 1990b, with respect to their engineering properties which include OMC, MDD, Soaked CBR, Liquid Limit, Classification and Sieve Analysis. The rice husk was burnt and prepared in a cylindrical incinerator to form the ash. The results of classification showed A-7-5, A-6, A-2-7 soils for Eke Obinagu, Egbede and Ugwuaji, respectively. The CBR values showed increase from $5 \%$ to $29 \%$, $7 \%$ to $13 \%$ and $5 \%$ to $23 \%$ for A-7-5, A-6 and A-2-7 respectively at optimal value of $17.5 \%$ stabilization. There was also an appreciable increase in the OMC values from $15 \%$ to $33 \%$, $14 \%$ to $25 \%$ and $15 \%$ to $31 \%$ for A-7-5, A-6 and A-2-7 soils respectively at $17.5 \%$ stabilization. Empirical models based on Scheffe's model were developed with the experimental results and the equations resulting from the second degree polynomials of Scheffe's models were solved using the least square method. The models developed showed close correlation with the experimental results for the A-7-5 and A-6 soils and will form good guide in pavement and foundation designs in the study areas.
\end{abstract}

Key words: Models, stabilization, CBR, RHA, clay.

\section{Introduction}

Soil as a material is easily the most abundant of all natural resources but yet very scarce when needed as a construction material. In developing countries, demand for this material is on a daily increase. With increase in road and building construction activities in the southeastern Nigeria, high demand has been placed on the soil with the result that those that qualify for use for construction purposes are almost out of stock. This creates an urgent need, in Nigeria as well as other areas round the globe, for increased effort towards improving any available soil, for use, within the locality. In road construction, the

Corresponding author: Iloeje Amechi Francis, M.Sc., research field: environmental management/architecture. E-mail: get2frankfast@gmail.com. underlying principle is to employ high quality sub grade materials to effect a substantial reduction in the thickness of pavement, thereby effectively reducing the overall cost of construction while still maintaining a long life span for the constructed road.

In the southeastern Nigeria, quality soils used for sub grade are in very short supply. Others are largely deficient in their engineering properties making them very unfit for use in construction and thus requiring some degree of stabilization to enhance the quality before use. In Enugu and Abia States, the study areas, huge quantities of waste materials are produced and the disposal mechanism does not match the rate of production, thereby creating environmental problems and hazardous situations. Adequate and safe disposal of such materials are very vital and can be addressed 
by finding ways to improve and utilize them for other useful purposes. Numerous works have been done on stabilization of soil using waste products and these have been able to prove that a substantial percentage of wastes when combined with other materials can produce highly beneficial results. One such material produced in large quantities, in the study areas, without adequate disposal plan, is the RHA (rice husk ash). This material can be harnessed and effectively used in combination with other materials to produce useful results. It has been classified into high carbon char, low carbon ash and carbon free ash [1]. Due to its refractory properties, it is most wanted in steel, ceramic and brick factories [2].

Several researchers carried out experimental studies on the use of this material to upgrade the soil properties. A study on strength characteristics of clay soil stabilized with lime and the ash was conducted by Ref. [3]. The unconfined compressive strength and soaked CBR (California Bearing Ratio) tests for different combinations of the stabilizing agents showed that $4 \%$ lime is very close to the optimal value either as sole additive or with any other secondary additive, from the view point of optimum efficacy. Ali and Sreenivasulu [4], also carried out an experimental investigation on the influence of the ash and lime on the Atterberg's limits, strength, compaction, swell and consolidation properties of bentonite. The results showed that the plasticity properties of bentonite were significantly modified upon their addition. There was also a noticeable influence of these materials on compaction, strength, swell and consolidation properties of bentonite soil particularly at $15 \%$ and $8 \%$ stabilization, respectively. Another study carried out by Chattopadhyay and Roy [5], explored the possibility of alternative materials like pond ash to be used wholly or partially for the construction of roads as well as manufacture of bricks. Mahmud and Muntohar [6], examined the possibilities of improving residual soil properties with this ash and cement in suitable proportions as stabilizing agents. Chandra et al. [7], used ash from rice mill and lime sludge from paper factory (all waste products), to demonstrate that the PI (plasticity index) value of clay soil decreases from twelve to eight when mixed with $10 \%$ ash and $16 \%$ lime sludge. Furthermore, with increase in the proportions of these materials, the dry density of the soil decreases whereas the OMC (optimum moisture content) increases. The UCS (unconfined compressive strength) was observed to have optimal value corresponding to $10 \%$ ash and $16 \%$ lime sludge. The soaked CBR value increases with increase in these materials. The optimal values of the proportions of these two materials for maximum UCS and lowest PI were estimated to be about $10 \%$ and $16 \%$, respectively. These results showed that these materials are excellent additives, in optimal proportions, for the stabilization of clayey soil. The stabilized soils can then be successfully employed for use as sub grade or sub-base for roads or pavement construction. While saving in construction costs, the environment is also rid of enormous deposits of waste.

Soil stabilization generally has been found to be useful in upgrading the bearing capacity of weak soils for building purposes. This has increased the potential benefits of using some waste products, against cement, as stabilizing agents. The major challenge now is to develop mathematical models that will encourage wider and easier application of soil improvement techniques.

This study will examine the use of the ash to upgrade an expansive clay soil, for use as a construction material. The percentage of this material that will generate better result in the engineering properties of the soil will also be examined with a view to formulating a model for RHA-Clay soil stabilization.

\section{Materials and Methods}

\subsection{Study Areas}

The soil samples were collected from three different locations of Enugu and Abia states, in the 
southeastern Nigeria. These locations are Borrow Pit sites for most of the road contracting firms in the states and they include: Eke-Obinagu Borrow Pit, Nike, Enugu state; Egbede Borrow Pit, Aba, Abia state and Ugwuaji Borrow Pit, Nkanu, Enugu state.

\subsection{Characterization of Clays}

Clays are rarely formed separately. They are mixed with other materials such as microscopic crystals of carbonates, feldspars, micas and quarts. Clay minerals are divided into four major groups: kaolinite, montmorillonite/smectite, illite and chlorite groups. The compositions of clay minerals depend on geographic area and the bedrock, and vary a lot all over the world. Clay soils have high plasticity index. According to Arora (2006), LL (liquid limit) is the water content at which the soil changes from liquid state to plastic state, while the PL (plastic limit), is the water content at which the soil changes from plastic state to semi-solid state. PI (plasticity index) is the numerical difference between the liquid limit and the plastic limit expressed as: $P I=(L L-P L)$. Soils with high PI indicate the presence of high proportion of clay fraction, while soils with lower PI tend to be silt.

\subsection{Characterization of $R H$ (Rice Husk) and RHA (Rice Husk Ash)}

$\mathrm{RH}$ (rice husk) is a by-product of the rice mill industry [8-10]. By weight, $10 \%$ of the rice grain is rice husk [11]. Jha and Gill [10] in their experimental study observed that for every 4 tons of rice, 1 ton is the rice husk. Similar study carried out by Alhassan [9], revealed that about 108 tons of rice hush is generated annually in the world. In Nigeria, about 2 million tons of rice are produced annually, while in Niger state alone, about 96,600 tons of rice grains are produced annually [12]. The husk generated from these will be enormous and is usually disposed carelessly by dumping in an open heap near the mill site or along the roadside where they are burnt.

An analysis of RH as given by Muthadhi et al. [13], is shown in Table 1.
The ash is obtained from burning the rice husk. When the husk is burnt, about $15 \%-20 \%$ turns into the ash. The ash, being so light, is carried away by wind and water in its dry state. It is difficult to coagulate and thus contributes to air and water pollution. The cumulative generation of the ash from rice requires a large space for disposal and so its utilization and the exploitation of its inherent properties provide a perfect way to mitigate the associated environmental problems. Researchers have found that this ash has high percentage of siliceous materials and so has potential pozzolanic properties [14]. According to Houstin [1], it has been classified into high carbon char, low carbon ash and carbon free ash. The properties depend on whether it has undergone complete destructive combustion or is partially burnt. Meanwhile, it has been categorized under pozzolana with about $67 \%-70 \%$ silica, $4.9 \%$ aluminum and $0.95 \%$ iron oxides [12].

\subsection{Sample Preparation and Experimental Program}

Soils from Eke Obinagu Borrow Pit, Emene, Enugu State, Egbede Borrow Pit, Aba, Abia State and Ugwuaji, Nkanu, Enugu State were used for this study, while the Rice Husk was sourced from Abakaliki in Ebonyi State, barely $75 \mathrm{~km}$ from Enugu. Only the CBR and OMC, were considered. The second degree polynomial was used to model their behavior and the effects on the soil properties.

On collection of the soil samples, they were first classified as given in Table 2, using BS 1377 standard

Table 1 Typical analysis of rice husk [13].

\begin{tabular}{ll}
\hline Properties & Range \\
\hline Bulk density $\left(\mathrm{kg} / \mathrm{m}^{3}\right)$ & $96-160$ \\
Length of husks $(\mathrm{mm})$ & $2-5$ \\
Hardness (Mohr's Scale) & $5-6$ \\
Ash (\%) & $22-29$ \\
Carbon (\%) & 35 \\
Hydrogen (\%) & $4-5$ \\
Oxygen (\%) & $31-37$ \\
Nitrogen (\%) & $0.23-0.32$ \\
Sulphur & $0.04-0.08$ \\
Moisture & $8-9$ \\
\hline
\end{tabular}


Table 2 Soil sample classification before stabilization.

\begin{tabular}{lll}
\hline No. & Properties & BS 1377 Classification \\
\hline 1 & Eke Obinagu & A-7-5 \\
2 & Egbede & A-6 \\
3 & Ugwuaji & A-2-7 \\
\hline
\end{tabular}

Source: Field work.

classification method.

After classification the engineering properties of the soil were determined in accordance with BS1377 and 1990b, and presented in Table 3, while the chemical properties of the rice husk ash were presented in Table 4.

The LL (liquid limits) of Eke Obinagu, Egbede and Ugwuaji were $61 \%, 40 \%$ and $49 \%$ before stabilization while their PI (plasticity index) were 35\%, 17\% and $18 \%$, respectively. These results indicate that Eke Obinagu soil with high PI can expand and shrink in response to wet and dry seasons of the year more than the rest of the soils. Other properties are as shown in Table 3. The burning and preparation of the ash was carried out in a cylindrical incinerator. The CBR test was carried out on the materials after stabilization. The moisture content of the soil generally represents the design conditions for which the test results were derived and this was also examined.

\section{Results, Discussions and Modeling}

Before stabilization the CBR value of Eke Obinagu (A-7-5) sample was 5\% and thereafter rose to $29 \%$ at optimal stabilization of $17.5 \%$. For Egbede (A-6) sample the CBR value was $7 \%$ before and $13 \%$ after, while it was $5 \%$ and $23 \%$ before and after respectively for Ugwuaji soil at $17.5 \%$ stabilization.

The CBR plot in Fig. 1 showed that not all the three samples met the sub-grade requirement. According to Nigerian Roads and Bridges specification [15], the CBR value of sub-grade should be up to $15 \%$ or more after soaking for $48 \mathrm{~h}$. Since the aim of this study is to know the soils that can respond favorably to stabilization with the ash, it was discovered that Eke Obinagu soil (A-7-5) with a CBR value of $29 \%$ responds
Table 3 Engineering properties of the soil.

\begin{tabular}{|c|c|c|c|c|}
\hline \multirow[b]{2}{*}{ S/No } & \multirow[b]{2}{*}{ Properties } & \multicolumn{3}{|c|}{ Location } \\
\hline & & $\begin{array}{l}\text { Eke } \\
\text { Obinagu }\end{array}$ & Egbede & Ugwuaji \\
\hline 1 & $\mathrm{OMC}(\%)$ & 15 & 14 & 15 \\
\hline 2 & $\operatorname{MDD}\left(\mathrm{gkm}^{3}\right)$ & 1.72 & 1.97 & 1.88 \\
\hline 3 & Soaked CBR (\%) & 5.00 & 6.00 & 5.00 \\
\hline 4 & Liquid limit (\%) & 61 & 40 & 49 \\
\hline 5 & Plasticity index (\%) & 35 & 17 & 18 \\
\hline 6 & $\begin{array}{l}\text { \% passing B.S. } \\
\text { Sieve size } 63 \mathrm{~mm}\end{array}$ & 65 & 39 & 57 \\
\hline 7 & Soil classification & A-7-5 & A- 6 & A-2-7 \\
\hline
\end{tabular}

Source: Field work.

Table 4 Chemical properties of the RHA.

\begin{tabular}{lll}
\hline $\begin{array}{l}\text { Compound } \\
\text { composition }\end{array}$ & $\begin{array}{l}\text { Rice husk ash at } \\
400{ }^{\circ} \mathrm{C}(\%)\end{array}$ & $\begin{array}{l}\text { RHA obtained from } \\
\text { open air }(\%)\end{array}$ \\
\hline $\mathrm{SiO}_{2}$ & 86.56 & 89.15 \\
$\mathrm{CaO}$ & 2.97 & 2.10 \\
$\mathrm{MgO}$ & 2.14 & 1.32 \\
$\mathrm{Fe}_{2} \mathrm{O}_{3}$ & 0.63 & 0.18 \\
$\mathrm{Al}_{2} \mathrm{O}_{3}$ & 3.65 & 4.32 \\
$\mathrm{Na}_{2} \mathrm{O}$ & 2.701 & 1.48 \\
$\mathrm{~K}_{2} \mathrm{O}$ & 1.251 & 1.399 \\
\hline
\end{tabular}

Source: Field work.

better than the other two soils. However in all the soil samples the addition of ash resulted in increase in the CBR values.

The models shall be obtained based on Sheffe's model given as:

$$
E_{(y)}=\beta_{o}+\sum_{i=1}^{p} \beta_{i} x_{i}^{2}+\sum \sum_{i<j}^{p} \beta_{i j} x_{i} x_{j}+\ldots \ldots+C
$$

which is the equation of independent variables for $2 \mathrm{nd}$ degree polynomial, where $p$ is the number of components in the mixture. It is worthy of note that interests among researchers have changed from determining which process variables affect the response, to determining the region or important factors that lead to the best possible response [16]. Response surface methodology RSM is a collection of mathematical and statistical techniques useful for the analysis and modeling of problems in which a response of interest is influenced by several variables and the objective is to optimize this response [16-18]. RSM methods lead to product OPTIMIZATION 
which is the main object of Scheffe's model. If the RHA variable is assumed to be $x_{1}$, while the soil variable is $x_{2}$, the number of components in the mixture is, $p=2$. The constraint of Scheffe's Model for a mixture design is that

$$
\begin{gathered}
x_{1}+x_{2}+\cdots x_{\mathrm{p}}=1 \quad x_{1}+x_{2}=1 \\
E_{(y)}=F_{f}=\left(\beta_{0}+\beta_{1}+\beta_{11}\right) x_{1}+\left(\beta_{0}+\beta_{2}+\beta_{22}\right) x_{2}+\left(\beta_{12}-\right. \\
\left.\beta_{11}-\beta_{22}\right) x_{1} x_{2}=\mu_{1} x_{1}+\mu_{2} x_{2}+\mu_{2} x_{1} x_{2}
\end{gathered}
$$

Put in a compact form,

$$
F_{f}=\sum_{1<i<p}^{p} \mu_{i} x_{i}+\sum \sum_{1<i<j<q}^{p} \mu_{i j} x_{i} x_{j}
$$

The result of the least square method is a system of linear equations with three unknown constants $\mu_{1}, \mu_{2}$, $\mu_{12}$, which will be determined for each of the soils obtained from the three locations. From Table 5 the least square is as shown in Table 6 and the homogenous equations for the model coefficients are as follows using Eke Obinagu soil sample:

Table 6 is generated for all the locations:

Eke Obinagu $\mathrm{CBR}=14.6469 x_{1}+0.05 x_{2}-0.1487 x_{1} x_{2}(5)$

Egbede CBR $=1.7559 x_{1}+0.0575 x_{2}+0.0257 x_{1} x_{2}(6)$

Ugwuaji CBR $=7.6021 x_{1}+0.0464 x_{2}-0.0743 x_{1} x_{2}(7)$

The above models can be verified using the optimum results of the stabilized soils given in Table 7.

The results of both the experiments and the model values are compared as shown in Tables 8-10 and in Figs. 1-3.

In all the soil types the addition of the stabilizing agent resulted in increase in CBR values, collaborated

\begin{tabular}{|c|c|c|c|c|c|c|c|c|c|c|}
\hline \multirow{2}{*}{ SN } & \multirow{2}{*}{ RHA (\%) } & \multicolumn{3}{|c|}{ Ugwuaji Nkanu A-2-7 } & \multicolumn{3}{|c|}{ Egbede Borrow PIT A-6 } & \multicolumn{3}{|c|}{ Eke-Obinagu A-7-5 } \\
\hline & & $\mathrm{OMC}(\%)$ & $\operatorname{MDD}\left(\mathrm{g} / \mathrm{cm}^{3}\right)$ & CBR $(\%)$ & $\mathrm{OMC}(\%)$ & $\operatorname{MDD}\left(\mathrm{g} / \mathrm{cm}^{3}\right)$ & CBR $(\%)$ & $\mathrm{OMC}(\%)$ & $\operatorname{MDD}\left(\mathrm{g} / \mathrm{cm}^{3}\right)$ & CBR $(\%)$ \\
\hline 1 & 0.00 & 15.00 & 1.88 & 5.0 & 14.00 & 1.97 & 6.00 & 15.00 & 1.72 & 5.00 \\
\hline 2 & 2.5 & 15.00 & 1.86 & 5.0 & 14.00 & 1.94 & 7.00 & 16.00 & 1.69 & 6.00 \\
\hline 3 & 5.00 & 17.00 & 1.82 & 7.0 & 14.00 & 1.90 & 9.00 & 18.00 & 1.63 & 7.00 \\
\hline 4 & 7.5 & 18.00 & 1.78 & 9.00 & 15.00 & 1.80 & 10.00 & 23.00 & 1.60 & 8.00 \\
\hline 5 & 10.00 & 20.00 & 1.68 & 15.0 & 15.00 & 1.62 & 11.00 & 26.00 & 1.48 & 22.00 \\
\hline 6 & 12.50 & 23.00 & 1.58 & 17.00 & 22.00 & 1.50 & 11.0 & 27.00 & 1.44 & 23.00 \\
\hline 7 & 15.00 & 29.00 & 1.49 & 22.00 & 23.00 & 1.44 & 13.00 & 28.00 & 1.41 & 28.00 \\
\hline 8 & 17.50 & 31.00 & 1.44 & 23.00 & 25.00 & 1.33 & 12.00 & 33.00 & 1.37 & 29.00 \\
\hline 9 & 20.00 & 30.00 & 1.40 & 18.00 & 27.00 & 1.28 & 9.00 & 33.00 & 1.34 & 26.00 \\
\hline
\end{tabular}
with the results of the models. The CBR curve for the model is linear while that of the experiment increased

Table 5 Results after stabilization (OMC, MDD, CBR).

\begin{tabular}{|c|c|c|c|c|c|c|c|}
\hline \multirow{2}{*}{ S/No } & \multirow{2}{*}{ RHA (\%) } & \multicolumn{2}{|c|}{ Eke Obinagu A-7-5 } & \multicolumn{2}{|c|}{ Egbede A-6 } & \multicolumn{2}{|c|}{ Ugwuaji A-2-7 } \\
\hline & & $\mathrm{OMC}(\%)$ & CBR (\%) & OMC (\%) & CBR $(\%)$ & $\mathrm{OMC}(\%)$ & CBR (\%) \\
\hline 1 & 15.00 & 28.0 & 28.0 & 23.0 & 13.0 & 29.0 & 22.0 \\
\hline 2 & 17.50 & 33.0 & 29.0 & 25.0 & 12.0 & 31.0 & 23.0 \\
\hline 3 & 20.00 & 33.0 & 26.0 & 27.0 & 9.00 & 30.0 & 18.0 \\
\hline
\end{tabular}

Table 6 Controllable variables for optimum moisture content.

\begin{tabular}{lrrrrrrrr}
\hline S/NO & \multicolumn{1}{c}{$X_{1}$} & \multicolumn{1}{c}{$X_{2}$} & \multicolumn{1}{c}{$X_{1} X_{2}$} & \multicolumn{1}{c}{$X_{1}{ }^{2}$} & \multicolumn{1}{c}{$X_{2}^{2}$} & \multicolumn{1}{c}{$X_{1}^{2} X_{2}$} & \multicolumn{1}{c}{$X_{1} X_{2}{ }^{2}$} & \multicolumn{1}{c}{$X_{1}^{2} X_{2}^{2}$} \\
\hline 1 & 0.00 & 100.00 & 0.00 & 0.00 & $10,000.00$ & 0.00 & 0.00 & 0.00 \\
2 & 2.50 & 97.50 & 243.75 & 6.25 & $9,506.25$ & 609.38 & $23,765.63$ & $59,414.06$ \\
3 & 5.00 & 95.00 & 475.00 & 25.00 & $9,025.00$ & $2,375.00$ & $45,125.00$ & $225,625.00$ \\
4 & 7.50 & 92.50 & 693.75 & 56.25 & $8,556.25$ & $5,203.13$ & $64,171.88$ & $481,289.06$ \\
5 & 10.00 & 90.00 & 900.00 & 100.00 & $8,100.00$ & $9,000.00$ & $81,000.00$ & $810,000.00$ \\
6 & 12.50 & 87.50 & $1,093.75$ & 156.25 & $7,656.25$ & $13,671.88$ & $95,703.13$ & $1,196,289.06$ \\
\hline$\Sigma$ & 37.50 & 562.50 & $3,406.25$ & 343.75 & $52,843.75$ & $30,859.38$ & $309,765.63$ & $2,772,617.19$ \\
\hline
\end{tabular}

Table 7 CBR/OMC values (for $15 \%, 17 \%$ and $20 \%$ stabilization). 
Table 8 CBR values for the model and experimental results (Eke Obinagu).

\begin{tabular}{lllll}
\hline S/No & RHA (\%) & Soil sample (\%) & CBR experiment (\%) & CBR Model (\%) \\
\hline 1 & 15.0 & 85.0 & 28 & 23.24 \\
2 & 17.50 & 82.50 & 29.0 & 29.59 \\
3 & 20.0 & 80.0 & 26.0 & 36.89 \\
\hline
\end{tabular}

Table 9 CBR values for the model and experimental results (Egbede Sub-base).

\begin{tabular}{lllll}
\hline S/No & RHA (\%) & Soil sample \% & CBR experiment (\%) & CBR model (\%) \\
\hline 1 & 15.0 & 85.0 & 13.0 & 11.3 \\
2 & 17.50 & 82.50 & 12.0 & 11.12 \\
3 & 20.0 & 80.0 & 9.0 & 10.6 \\
\hline
\end{tabular}

Table 10 CBR values for the model and experimental results (Ugwuaji Sub-base).

\begin{tabular}{lllll}
\hline S/No & RHA (\%) & Soil sample (\%) & CBR experiment (\%) & CBR model (\%) \\
\hline 1 & 15.0 & 85.0 & 22.0 & 34.36 \\
2 & 17.5 & 82.5 & 23.0 & 45.76 \\
3 & 20.0 & 80.0 & 18.0 & 59.02 \\
\hline
\end{tabular}

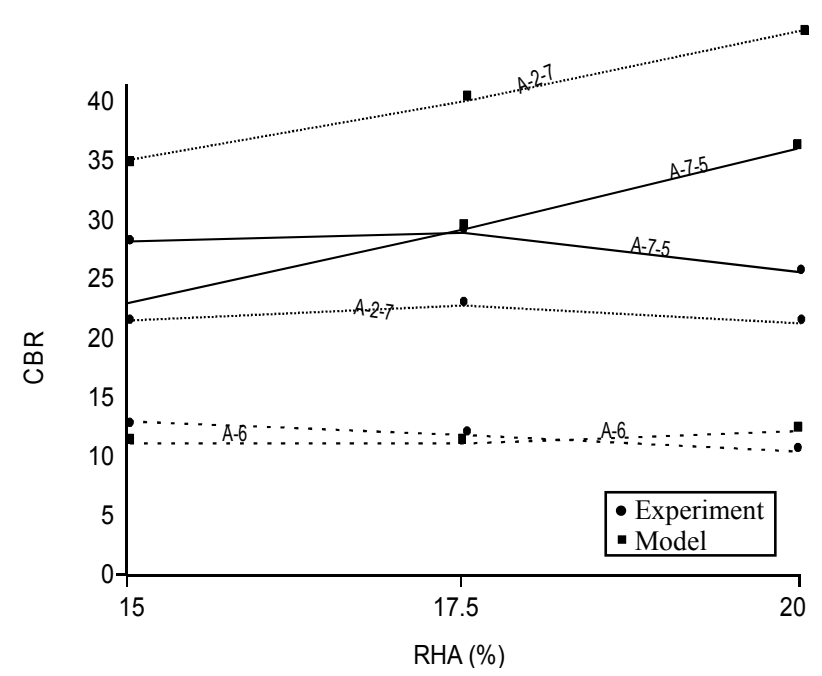

Fig. 1 Combined plot of CBR against RHA.

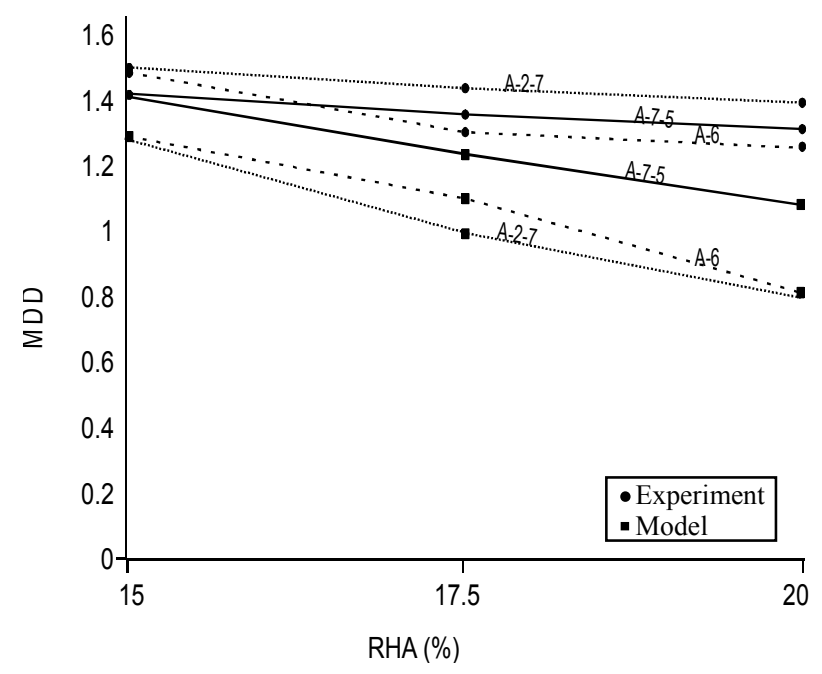

Fig. 2 Combined plot of MDD against RHA.

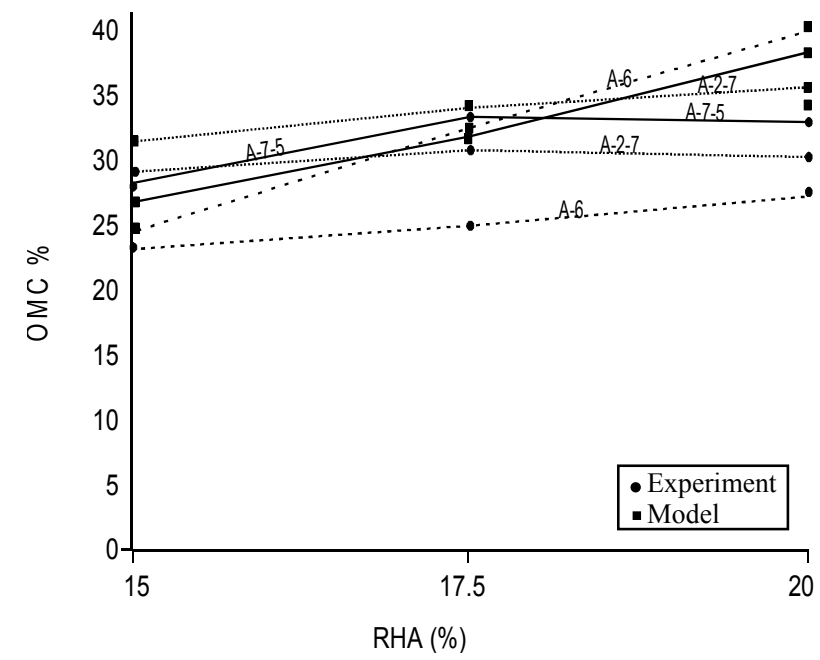

Fig. 3 Combined plot of OMC against RHA.

slightly and decreases linearly at $17.5 \%$ stabilization for the Ugwuaji. Decrease in CBR value when the agent is increased suggests that the lack of cementing properties is a disadvantage to its use as a stabilizer for expansive soils. For this reason, it should be used with lime-containing material or cement for soil improvement.

\section{Conclusions}

The results of the models closely correspond with the experimental results especially with A-7-5 and A-6 soils and so the models could be used to predict the Siol-RHA properties in the absence of 
experimental results. In all the soil types, the addition of the stabilizing agent resulted in increase in OMC and CBR values similar to results from other literatures on the subject. At $15 \%$ to $17.5 \%$ stabilization the soils attained their maximum CBR values although the A-6 soil had the lowest values. These behavioral changes were also observed in the results of the models but the pattern of improvement varies with the different soils. This study therefore recommends that thus: Although ash from rice is a good stabilizing agent for expansive soils it will require lime-containing material or cement to achieve better results, the empirical models developed could be used to predict the properties of the stabilized soil in the absence of experimental data for the A-7-5 and A-6 soils.

\section{References}

[1] D.F. Houstin, Rice Chemistry and Technology, American Association of Cereal Chemistry, Inc., St. Paul, Minnesota, 1972, pp. 301-340.

[2] C.S. Prasas, K.N. Maiti, R. Venugopal, Effect of RHA in white wave composition, Ceramics International 27 (2000) 629.

[3] G.V.R.P. Raju, B.P.C. Sekhar, B.R.P. Kumar, G. Mariyana, Strength characteristics of expansive soils stabilized with lime and rice husk ash, in: Proceedings of the National Seminar on Road Transportation: Issues and Strategies, Patiala, 1998, p. 20.

[4] M. Ali, V. Sreenivasulu, An experimental study on the influence of rice husk ash and lime on properties of bentonite, in: Proceedings of the Indian Geotechnical Conference, India, 2004, p. 468.

[5] B.C. Chattopadhyay, T.K. Roy, Uses of soil as road material with different technologies for improvisation, in: Proceedings of the National Conference on Advances in
Road Transportation (ART), NIT Rourkela, 2005, p. 491.

[6] E.A. Basha, R. Hahim, H.B. Mahmud, A.S. Muntohar, Stabilization of residual soil with RHA and cement, Journal of Construction and Building Materials 19 (6) (2005) 448-553.

[7] S. Chandra, S. Kumar, R.K. Anand, Soil stabilization with rice husk ash and lime sludge, Journal of Indian Highways 33 (5) (2005) 87-98.

[8] J.K. Mitchell, Practical problems from surprising soil behavior, J. Geotechnical Engineering 112 (3) (1996) 255-289.

[9] M. Alhassan, Potential of rice husk ash for soil stabilization, AU Journal of Technology 11 (4) (2008) 246-250.

[10] J.N. Jha, K.S. Gill, Effect of rice husk ash on lime stabilization, Journal of the Institute of Engineering India, 87 (2006) 33-39.

[11] P.K. Mehta, Concrete Structure, Properties and Materials, Prentice-Hall Eagle-Wood Cliffs, New Jersey, 1986, pp. 256-289.

[12] E.B. Oyetola, M. Abdullahi, The use of rice husk ash in low-cost sandcrete block production, Leonardo Electronic Journal 8 (2006) 58-70.

[13] A.C. Muthadhi, R. Anitha, S. Kothandaraman, Rice husk ash-Properties and its uses, A Review IE (I) Journal 88 (2007) 50-56.

[14] D.J. Cook, R.P. Pama, S.A. Damer, Rice husk ash as a pozzolanic material, in: Proceeding of Conference on New Horizons in Construction Materials, Lehigh University, Lehigh, 1976.

[15] Specification Limits for Materials for Roads and Bridges, Federal Ministry of Works, Nigeria, 1997.

[16] D.C. Montgomery, Designs and Analysis of Experiments, 6th ed., John Wiley and Sons, New York, 2005.

[17] R.H. Myers, D.C. Montgomery, G.C. Vining, C.M. Borror, S.M. Kowalski, Response surface methodology: A retrospective and literature survey, Journal of Quality Technology 36 (2004) 53-77.

[18] R.H. Myers, D.C. Montgomery, A tutorial on generalized linear models, Journal of Quality Technology 29 (1997) 274-291. 